\title{
Life Insurer Cost of Equity with Asymmetric Risk Factors
}

\author{
Vickie L. Bajtelsmit ${ }^{1}$ Sriram V. Villupuram ${ }^{2}$ Tianyang Wang ${ }^{3}$
}

\begin{abstract}
This study presents an improved model for estimating life insurer cost of capital with the inclusion of upside and downside risk factors and controlling for life insurer characteristics. Although various asymmetric measures of market risk have been shown to be priced factors for the broader equity market, life insurer realized equity returns include a much larger premium for bearing downside risk, even after controlling for firm characteristics and other measures of risk. Cross-sectional regression analysis finds a positive (negative) premium for downside (upside) betas, conditional on down and up markets respectively. Coskewness and cokurtosis are also priced factors.
\end{abstract}

Keywords: Cost of equity; Upside risk; Downside risk; Equity market; Life insurance industry, Prospect theory.

JEL Code: G12, G22, D81

\footnotetext{
${ }^{1}$ Department of Finance and Real Estate, Colorado State University, Fort Collins, CO 80523, USA; Phone: 1-970491-0610; Email: Vickie.bajtelsmit@colostate.edu

${ }^{2}$ Corresponding author. Department of Finance and Real Estate, University of Texas at Arlington, Arlington, TX 76019, USA; Phone: 1-817-272-3705; Fax: 1-817-272-2252; Email: sriramv@uta.edu

${ }^{3}$ Department of Finance and Real Estate, Colorado State University, Fort Collins, CO 80523, USA; Phone: 1-970491-2381; Email: tianyang.wang@business.colostate.edu
} 


\section{Life Insurer Cost of Equity with Asymmetric Risk Factors}

\section{Introduction}

In the insurance industry, the cost of equity is an important factor in pricing, performance, and reserving. Investors, regulators, and managers benefit from more precise measurement of expected equity returns. There is literature that incorporates unique industry factors in modeling insurer cost of equity (Cummins and Phillips, 2005; Wen, Martin, Lai and O’Brien, 2008; Nissim, 2013). Insurance regulators are particularly concerned about underestimation of the cost of equity because it can result in inadequate reserves and increased risk of financial distress. Although this can be an issue for all types of insurers, it is more important for life insurers because of the long term nature of their liability portfolio. This paper provides an improved model for estimating life insurer cost of equity with the inclusion of upside and downside market risk factors and controlling for specific life insurer characteristics and risk factors. We find that life insurer realized equity returns include a much larger premium for bearing downside risk than is typical in the broader equity market.

The traditional and most common approaches for estimating the cost of equity capital are based on the capital-asset pricing model (CAPM) model (Sharpe, 1964; Lintner, 1965; Mossin, 1966) and the Fama-French three-factor (FF3F) model (Fama and French, 1992, 1996). Both models assume that stock returns symmetrically relate to market movements and other factors, which implies that the cross-sectional risk-return relationship is robust to either up or down markets. However, behavioral finance and decision theory suggests that individual decisionmakers tend to be loss averse and disappointment averse Kahneman and Tversky (1979). In an expected utility framework, asymmetric attitudes towards risk cause individuals to overweight the disutility of a potential loss relative to the positive utility from a potential gain. Although asymmetric risk factors have been shown to be priced in the broader cross-section of stocks (Ang, Chen and Xing, 2006), unique characteristics of the life insurance industry imply that investors may weight downside risk for these companies more heavily. 


\subsection{Prospect theory and downside risk for life insurers}

The economics and finance literatures recognize that investors perceive and react to gains and losses differently (Roy, 1952; Markowitz, 1959; Bawa and Lindenberg, 1977; Maurice, Uppal and White, 1993; Barberis and Huang, 2001; You and Daigler, 2010). Many studies also find support for asymmetric preference directions toward higher moments of investment return distributions (e.g. Rubinstein, 1973; Gooding, 1976; Scott and Horvath, 1980; Benishay, 1992; Lambert and Hübner, 2013). The theoretical explanation for asymmetric attitudes toward upside and downside risk, discussed by Gul (1991), has its foundations in prospect theory (Kahneman and Tversky, 1979) and is based on a rational disappointment-averse utility function that embeds downside risk. This utility function places higher weights on disappointing outcomes and implies a greater risk premium on downside risk. Ang, Chen and Xing (2006) provide a detailed development of how downside risk is priced cross-sectionally in an equilibrium setting with disappointment-averse utility preferences.

Although financial stocks are normally classified as cyclical, life insurers are different from other financial firms in several respects such that asymmetric risk may be more important for investors in this industry group than for the broader market. In their review of the literature on life insurance demand factors, Liebenberg, Carson and Dumm (2012) point out that the relatively long duration of asset and liability portfolios differentiate these firms from those in other industries. Due to their unique role in providing financial stability to individuals and businesses and their exposure to the financial markets, regulators and academic researchers focus their attention on life insurers insolvency risk (Cummins and Phillip, 2009; Browne, Carson and Hoyt, 2001).

Recent studies suggest that insurers are exposed to greater than-average systematic downside risk. For example, Harrington (2009) and Grace (2010) identify several contributing factors that make life insurers more sensitive to negative financial environments, including higher leverage, asset sensitivity to interest rate changes, and potential policyholder withdrawals (negative cash-flows) during financial downturns. Chen, Cummins, Viswanathan, and Weiss (2014) investigate the interconnectedness between banks and insurers by using daily market value data on credit default swap spreads and intraday stock prices to measure systemic risk in the insurance sector during the financial crisis. TheyFind that banks create significant systemic 
risk for insurers but not vice versa. Cummins and Weiss (2014) conclude that life insurers are vulnerable to intra-sector crises because of leverage and liquidity risk, and to reinsurance crises arising from counterparty credit exposure.

Related literature on stock price reactions to insurer rating changes also suggests that investors react differently to upside and downside risk for these firms. For example, using a sample of rating changes by A.M. Best, S\&P, and Moodys from 1993 to 2003, Halek and Eckles (2010) show that insurer rating downgrades are associated with an approximately $7 \%$ decline in stock price. In contrast, insurer rating upgrades have an insignificant impact. Miao, Ramchander and Wang (2013) examine the impact of rating changes on insurance company bonds with more recent data for the period from 2005 to 2010 . They show that downgrades of insurer financial ratings are associated with a negative bond price reaction and that upgrades have no measurable impact on bond prices. Chen, Chen, Sun, Yu and Zhong (2013) also find that the credit spreads of insured bonds increase significantly after insurers are downgraded or put on the negative watch list.

Although some of the issues discussed above may apply to property and casualty insurers, previous research suggests that asset and liability portfolios, product mix, and exposure to systematic risk significantly differentiate the property and casualty industry from the life insurance industry. Whereas the majority of property and casualty insurance contracts are for one year or less, life insurance liabilities are primarily multiyear contracts, such as permanent life insurance and annuities. As a result, life insurers tend to be more heavily invested in long-term interest-bearing assets than property and casualty insurers. Property and casualty insurers are also exposed to unique factors that are not relevant to life insurers, such as the widely-studied underwriting cycle (e.g., Cummins and Outreville, 1987; Fung, Lai, Patterson and Witt, 1998; Cummins and Phillips, 2005). We purposefully do not include property and casualty insurers in our main sample due to significant differences between these two industries and provide more discussion on the property and casualty insurers in section 3.3.

We hypothesize that investors have higher downside risk aversion toward life insurers for two primary reasons. First, the industry's reputation as a provider of long-term security may lead investors to assume that insurance company stocks are safer, and perhaps countercyclical, investments. The behavioral explanation for this is that investors are subject to a 
representativeness bias which causes them to mistake company, product, or brand characteristics for stock investment characteristics (Solt and Statman, 1989; Aspara, 2013). If insurance stocks are bought for their perceived long term safety, performance to the contrary of these expectations may cause quicker sell decisions, resulting in steeper declines than in the broader market. Second, investors may exhibit differential upside and downside risk aversion due to anticipation of disintermediation effects. As with other financial services firms, life insurer profits are heavily dependent on investment returns, particularly as the product mix has shifted toward more combined investment and insurance products, such as variable annuities. Campbell and Vuolteenaho (2004) find that long-term investors are more sensitive to decrease in cash-flows than they are to the increase in interest/discount rate movement. Therefore, investors may be more sensitive to downside equity market performance because of the increased risk of disintermediation (negative cash-flows), as policyholder lapse-rates may increase when illustrated returns are not realized. Because policyholders do not have more attractive investment alternatives during low-rate periods, co-movement of insurance company stock returns with interest rates is insufficient to explain asymmetric market risk attitudes. Notably, disintermediation does not play as great a role for property and casualty insurers because their products do not explicitly include investment components.

\subsection{Downside risk and life insurer cost of equity}

The finance literature identifies many factors that are priced by equity investors. In addition to the common factors of market excess return, size, and book-to-market, recent studies find that various measures of asymmetry may be significant determinants of excess returns. Of particular interest, asymmetric risk can be measured by upside beta and downside beta, where upside (downside) beta measures a stock's co-movement with the market conditional on the market return being above (below) its mean excess return (Bawa and Lindenberg, 1977; Kim and Zumwalt, 1979).

Ang, Chen and Xing (2006) confirm the predictions of prospect theory by finding that, for a broad cross-section of stocks covering the period 1963 to 2001, investors place greater weight on downside risk and demand additional compensation for holding stocks with high sensitivities to downside market movements. Their paper provides a more complete discussion of asymmetric risk measures, with robustness checks on the method. A priori, it is unclear whether 
their results are robust to individual industries and to recent market conditions. While the cost of equity has been of increasing interest, the insurance literature has not previously included asymmetric risk in cost of equity estimation models (Cummins and Phillips, 2005; Wen, Martin, Lai, and O'Brien 2008; Nissim, 2013). We examine the asymmetric co-movement of life insurer stock returns with the broader equity market and estimate the associated risk premiums for asymmetric measures of risk. We hypothesize that upside and downside market risks are important to life insurance company investors and that the premium for bearing downside risk will exceed those found by Ang, Chen and Xing (2006) for the broader cross-section of stocks. As discussed in the previous section, investors may find downside risk to be more informationally relevant for life insurers due to a priori expectations of risk and return.

We compare the effect of asymmetric market risk on required rates of return before and after the financial crisis. Ang, Chen and Xing (2006) study includes a long time series, but it does not cover the recent period of unprecedented stock market volatility in an artificially low interest rate environment. This suggests that re-estimation of equity factors for this unique economic climate is warranted.

We estimate the cost of equity for life insurance companies using the Fama-MacBeth (1973) method and controll for other known risk factors, including size, book-to-market, volatility, momentum, coskewness, cokurtosis, and liquidity beta. Whereas Ang, Chen and Xing (2006) covers all stocks traded on the NYSE from 1963 to 2001, our sample focuses on publiclytraded life insurers for the period from 1990 to 2012. By narrowly focusing on a single industry, we are able to control for unique industry characteristics and develop a more robust pricing model for life insurer cost of equity. Our data period allows us to evaluate whether the financial crisis impacted investor attitudes toward upside and downside risks.

The major contribution of this we provide is an improved model for estimating life insurer cost of equity capital with the inclusion of upside and downside market risk factors and controlling for specific life insurer characteristics and risk factors. In contrast to previous studies for the broader equity market, the estimated $16.9 \%$ risk premium for bearing downside risk in life insurance stocks is approximately three times the premium for the cross section of general equity stock returns. The downside risk premium is slightly higher in the pre-financial crisis period. When traditional size and book-to-market variables are replaced with equivalent 
insurance-related controls, downside risk continues to be a significant pricing factor. The results of this study demonstrate that investor loss aversion and its impact on stock pricing can be unique to an industry.

\section{Data and Models}

\subsection{Sample description}

The sample consists of 108 publicly-traded U.S. life insurance companies, identified by SIC code 6311, for the period from 1990 to 2012. We obtain share price, shares outstanding, and volume from Center for Research in Securities Prices (CRSP) and relevant financial statement data on these firms from COMPUSTAT. The sample period begins in 1990 because COMPUSTAT has very limited data for insurance companies before that year. Table 1 provides the summary statistics for the sample.

\section{[Insert Table 1 Here]}

\subsection{Measures of life insurer equity return and risk}

We calculate continuously-compounded daily excess returns for each life insurer and the market. The market proxy is the CRSP value-weighted equity return index. ${ }^{1}$ Using these measures of returns, we construct several measures of risk, including the traditional CAPM beta $(\beta)$, downside beta $\left(\beta^{-}\right)$and upside beta $\left(\beta^{+}\right)$as described below. The traditional CAPM beta is calculated as:

$$
\beta=\frac{\operatorname{cov}\left(r_{i}, r_{m}\right)}{\operatorname{var}\left(r_{m}\right)}
$$

where $r_{i}$ and $r_{m}$ are the excess returns of life insurance company $i$ and that of the market index respectively. Consistent with Ang, Chen and Xing (2006), we follow Kothari, Shanken and Sloan (1995) and estimate betas in overlapping periods of 12 months using daily returns. Although cross-sectional asset pricing studies often use monthly data over longer intervals, estimating factor loadings using higher frequency data over shorter samples provides a larger number of observations and improves the power of the model results. Further, the use of daily

\footnotetext{
${ }^{1}$ We also examine and confirm that our findings hold using an equal-weighted equity return index.
} 
data allows for better identification of downside price movements which may not be as evident in smoothed monthly price series.

We then decompose the CAPM beta into its downside and upside components. Downside beta $\left(\beta^{-}\right)$, first introduced by Bawa and Lindenberg (1977), captures the correlation between the firm's excess return and the market excess return, conditional on the market realized excess return $\left(r_{m}\right)$ being less than the market average excess return $\left(\mu_{m}\right)$ over the 12 month period. More formally, downside beta $\beta^{-}$is computed as:

$$
\beta^{-}=\frac{\operatorname{cov}\left(r_{i}, r_{m} \mid r_{m}<\mu_{m}\right)}{\operatorname{var}\left(r_{m} \mid r_{m}<\mu_{m}\right)}
$$

If a life insurance company's stock price tends to move downward in a declining market more than it moves upward in a rising market, it is an unattractive asset to hold for risk averse investors who are sensitive to downside losses, relative to upside gains. Therefore, investors would require a premium for holding stocks with high sensitivities to downside market movements. For the broader cross-section of stocks, Ang, Chen and Xing (2006) estimate that the downside equity risk premium is approximately $6 \%$. However, we expect investors will require a higher risk premium for bearing downside risk when investing in life insurance stocks because of perceived greater sensitivity of this industry to downside market movements and representativeness bias that leads them to believe that life insurers have lower downside exposure.

Upside beta $\left(\beta^{+}\right)$is defined similarly and is calculated as:

$$
\beta^{+}=\frac{\operatorname{cov}\left(r_{i}, r_{m} \mid r_{m}>\mu_{m}\right)}{\operatorname{var}\left(r_{m} \mid r_{m}>\mu_{m}\right)}
$$

where covariance and variance are conditional upon the market realized excess return $\left(r_{m}\right)$ being greater than the market average excess return $\left(\mu_{m}\right)$ for the 12 month period. Existing evidence on the role of upside beta in equity markets suggests that an investor is willing to hold stocks with high upside potential at a discount, all else being equal.

\subsection{Asymmetric risk before and after the financial crisis}

Figure 1 compares average realized traditional CAPM beta to the decomposed upside and downside betas for our sample of life insurers from 1990 to 2012. Prior to 2007, all three beta 
measures are consistently lower than 1.0 for this industry but they increase significantly in the years leading up to and during the financial crisis. Post-2010, the betas decline substantially, but remain at historically high levels.

[Insert Figure 1 Here]

In the $1990 \mathrm{~s}$, we see a consistent relationship $\beta^{+}<\beta<\beta^{-}$. However, this relationship reverses during the financial downturns in 2000 and post-2007 such that $\beta^{-}<\beta<\beta^{+}$. Although the three beta measures are clearly correlated throughout the sample period, the relationship changes after the financial crisis. Prior to 2007, the upside and downside risk measures move inversely to one another, conditional on the traditional CAPM, whereas the period during and after the financial crisis shows much greater co-movement. The increased correlation of stock returns during large market movements is a likely explanation. In a later section of the paper, we separately analyze the pre-financial crisis period as a robustness check.

\subsection{Other measures of asymmetric risk: coskewness and cokurtosis}

Stock return distributions have been shown to be skewed or leptokurtic rather than normally distributed. (Ané and Geman, 2000; Chung, Johnson and Schill, 2006). Therefore, we expect that each stocks contribution to systematic skewness (coskewness) and kurtosis (cokurtosis) may determine the stocks attractiveness and require risk premiums (Scott and Horvarth, 1980; Fang and Lai, 1997; Dittmar, 2002; Nguyen and Puri, 2009). Therefore, we examine two additional measures of higher-order asymmetric risk, coskewness and cokurtosis, calculated as

$$
\begin{aligned}
& \text { coskewness }=\frac{E\left[\left(r_{i}-\mu_{i}\right)\left(r_{m}-\mu_{m}\right)^{2}\right]}{\sqrt{\operatorname{var}\left(r_{i}\right) \operatorname{var}\left(r_{m}\right)}} \\
& \text { cokurtness }=\frac{E\left[\left(r_{i}-\mu_{i}\right)\left(r_{m}-\mu_{m}\right)^{3}\right]}{\sqrt{\operatorname{var}\left(r_{i}\right) \operatorname{var}\left(r_{m}\right)^{\frac{3}{2}}}}
\end{aligned}
$$

where $r_{i}$ and $r_{m}$ are the excess returns of insurance company $i$ and the market, and $\mu_{i}$ and $\mu_{m}$ the daily average excess return of insurance company $i$ and the market during the year. Coskewness is effectively the covariance of a stocks return with the square of the market return, or with the volatility of the market. Cokurtosis is effectively the covariance of a stock's return with the cube of the market return, or with the skewness of the market return distribution. 
The distribution of coskewness across stocks is negatively skewed and is negative on average. A stock with negative coskewness tends to have low returns in periods of high market volatility, which are commonly, but not always, periods of low market returns. In a broader equity cross-sectional study, Harvey and Siddique (2000) find that firms with high coskewness have lower returns and Dittmar (2002) finds that positive cokurtosis is associated with greater returns. Coskewness for this sample of life insurers is generally negative each year and cokurtosis is positive each year of the sample. Both coskewness and cokurtosis increase in magnitude and volatility after the financial crisis.

Volatility of the market treats upside and downside risk symmetrically, so both extreme upside and extreme downside movements of the market have the same volatility. In contrast, downside beta explicitly considers only the downside case. Therefore, coskewness could capture both downside risk and upside risk and should be controlled when analyzing asymmetric betas.

\subsection{Asymmetric risk measures and realized returns}

Table 2 illustrates the relationship between realized returns and $\beta, \beta^{+}, \beta^{-}$, respectively, sorted into terciles in our life insurer sample. ${ }^{2}$ Consistent with findings of many other portfolio beta studies, the single-sort tables in Panel A show a monotonically increasing relationship between realized returns and realized traditional CAPM $\beta$ for life insurers. For the portfolios sorted on traditional CAPM $\beta$, the average realized excess return on the low-tercile portfolio is 6.42 percentage points lower than the average realized excess return on the high-tercile portfolio and the difference is highly significant. In Panel A, we report the average downside and upside betas for each of the CAPM beta portfolios. Because these variables are, by construction, conditional on the CAPM beta, the spread in realized $\beta^{-}$and realized $\beta^{+}$are similar and are significantly different from zero. ${ }^{3}$

In Panels B and C of Table 2, we sort on upside and downside betas respectively to examine the relationship of these factors and realized returns. As with the results reported in Panel A,

\footnotetext{
${ }^{2}$ Although many portfolio beta studies use smaller divisions, such as deciles, the unit of measurement here is by tercile due to the smaller sample size.

${ }^{3}$ We also examine and confirm that our findings hold significantly using relative downside beta (given by $\beta^{-}-\beta$ ), relative upside beta (given by $\beta^{+}-\beta$ ), and the difference between upside beta and downside beta (given by $\beta^{+}-\beta^{-}$) as discussed in Ang, Chen and Xing (2006).
} 
stocks sorted on upside and downside risk exhibit monotonically increasing returns, and the difference between the return on the lowest and highest terciles is highly significant.

[Insert Table 2 Here]

The single sort results in Table 2 suggest that life insurance stocks with greater downside risk have contemporaneously higher realized returns. Additionally, the effect of downside beta is more pronounced than the traditional CAPM beta or the upside beta, which is consistent with earlier results for the broader cross-section of stocks in Ang, Chen and Xing (2006). This suggests that the life insurance investors may require a higher risk premium for bearing downside risk. We next examine whether this relationship is priced after controlling for other risk factors and the magnitude of the risk premium of insurer downside risk.

\subsection{The contemporaneous relationship between realized return and downside risk}

To examine the downside risk-return relationship for life insurance companies, we estimate Fama and MacBeth (1973) cross-sectional regressions of excess returns on realized risk factors. Using this method, we can focus on the reward to downside risk, while controlling for other cross-sectional effects discussed in the literature.

As a first step, we use historical returns to estimate the asymmetric variables, including upside and downside beta, coskewness, and cokurtosis. Following the Fama-MacBeth (1973) method, we estimate cross-sectional regressions each month including these and other factors hypothesized to affect life insurer returns. We report statistics on the distribution of the coefficient estimates over the entire sample period. The average coefficient for each type of risk represents its risk premium. A statistically significant positive (negative) coefficient indicates that it is a priced factor that will result in increased (decreased) expected returns for life insurance companies.

We estimate the risk premiums for each type of risk for each firm on the cross-sectional level. The Fama and MacBeth (1973) method consists of month-to-month cross-sectional 
regressions of the different asset returns. We average these estimates to get the average coefficients. ${ }^{4}$ The base case model can be expressed as in Equation 6:

$$
r_{i, t}=\alpha+\phi_{\beta} \beta_{i, t}+\sum_{i=1}^{n} \phi_{i} \gamma_{i, t}+\varepsilon_{i, t}
$$

where $r_{i, t}$ is the monthly excess return on company $i$ for month $t, \beta_{i, t}$ is the realized CAPM beta calculated at the end of every month using daily return data from the next twelve months, and $\gamma_{i, t}$ is a vector of controls for firm characteristics and sources of risk.

We are primarily interested in testing whether life insurer stockholders are rewarded for bearing downside risk to the same extent as in the broader cross-section of stocks. ${ }^{5}$ Therefore, the first set of models follow Ang, Chen and Xing (2006), with the standard controls for size (Banz, 1981), book-to-market (Basu, 1983), and momentum effects (Jegadeesh and Titman, 1993).

We control for market liquidity risk, as suggested by previous research (Pástor and Stambaugh, 2003) with the firm's liquidity beta $\beta_{i}^{L}$. We estimate this measure for each company by running the regression given by Equation 7 using the most recent five years of monthly data:

$$
r_{i, t}=\beta_{i}^{0}+\beta_{i}^{L} L_{t}+\beta_{i}^{M} r_{m, t}+\beta_{i}^{S} S M B_{t}+\beta_{i}^{H} H M L_{t}+\varepsilon_{i, t}
$$

where $L_{t}$ is the innovation in aggregate liquidity as defined in Pástor and Stambaugh (2003), and $S M B_{t}$ and $H M L_{t}$, are the size and book-to-market factors of Fama and French (1993) respectively. The estimated coefficients from these regressions measure the sensitivity of the insurers returns to the various characteristics of the broader equity market.

To assess the role of upside and downside beta, we estimate variations of the model described in Equation 6 substituting measures of asymmetric risk for traditional CAPM beta and including idiosyncratic volatility as measured by standard deviation, coskewness, and cokurtosis. Because the upside and downside betas are decompositions of the traditional beta, we do not

\footnotetext{
${ }^{4}$ This estimation method is different from that of other studies such as Wen, Martin, Lai and O'Brien (2008) in that the studies that employ Fama and French (1993) factors use a time-series of returns as factors, which are themselves risk premiums for each unit of risk.

${ }^{5}$ Arguably, the difference in magnitude of risk premia could be due to unique factors related to the earlier time period studied in Ang, Chen and Xing (2006). Although not reported here, the estimated downside risk premium for the general equity market using both our data sample periods is consistent with approximately $6 \%$, as in Ang, Chen and Xing (2006).
} 
include all three measures in any of our model specifications. Based on economic justification of the pricing factors and consistency with prior research, Model III, the preferred model, is specified in Equation 8.

$$
\begin{aligned}
& R_{i, t}=\alpha+\varphi_{\beta^{+}} \beta_{i, t}^{+}+\varphi_{\beta^{-}} \beta_{i, t}^{-}+\varphi_{S} \operatorname{Ln}_{(\text {Size })_{i, t}+\varphi_{B M} B / M_{i, t}+\varphi_{M} \text { Momentum }_{i, t}} \\
& \quad+\varphi_{V} \text { Volatility }_{i, t}+\varphi_{\text {CS }} \text { Coskewness }_{i, t}+\varphi_{C K} \text { Cokurtosis }_{i, t}+\varphi_{L} \beta_{L}+\varepsilon_{i, t}
\end{aligned}
$$

Wen, Martin, Lai and O'Brien (2008) find that insurer cost of equity is better estimated using industry-specific measures of firm characteristics. Therefore, we re-estimate the models substituting life insurance specific measures in place of $\ln ($ size $)$ and book-to-market. Specifically, we measure size by the log of the book value of assets and we measure leverage as the book value of assets less the book value of equity, divided by the book value of assets. All independent variables are winsorized at the $1 \%$ and $99 \%$ levels to avoid placing too much emphasis on extreme observations. Variable definitions are summarized below:

- $\beta_{i, t}, \beta_{i, t}^{-}$, and $\beta_{i, t}^{+}$: the realized traditional CAPM, downside, and upside betas, calculated every month using daily return data from the next twelve months (Equations 1,2, and 3).

- Size $_{i, t}$ : firm size, measured as either the market capitalization (the number of shares outstanding at the end of previous year multiplied by the share price) or, the book value of assets.

- $\quad$ Book-to-Market ${ }_{i, t}\left(B / M_{i, t}\right)$ : the most recent quarterly book value of insurance company $i$ divided by its market value.

- $\quad$ Leverage $_{i, t}$ : (Book Value of Assets - Book Value of Equity)/Book Value of Asset.

- $\quad$ Momentum $_{i, t}$ : past twelve months excess return for company $i$ in month $t$.

- Volatility $_{i, t}$ : realized standard deviation of the next twelve month of daily returns for company $i$ in month $t$.

- Coskewness $s_{i, t}$ : realized coskewness for company $i$ in month $t$ according to Equation 4 based on the next twelve months of daily returns. 
- Cokurtosis $i_{i, t}$ : realized cokurtosis for company $i$ in month $t$ according to Equation 5 based on the next twelve months of daily returns.

- $\quad \beta_{i, t,}^{L}$ : Pástor and Stambaugh (2003) historical liquidity beta, calculated the end of every month using the most recent five years of monthly data.

\section{Results}

\subsection{Cross-sectional regressions with traditional controls for size and leverage}

We perform a Fama and MacBeth (1973) two-pass cross-sectional procedure to test the significance of the asymmetric risk measures. The different model specifications are labeled as Models I through III and are reported on the left side of Table 3 for the full sample (1990-2012) and on the right side of Table 3 for the period prior to the financial crisis (1990-2006). The means and standard deviations for each control variable are given in the right hand columns.

[Insert Table 3 Here]

Table 3 shows results that are largely consistent with those found for the broader crosssection of stocks in the previous literature. The Model I results in the first column show that the traditional CAPM beta is not a priced factor after controlling for other factors. Given that CAPM betas are commonly used in equity pricing models, this is an interesting observation, suggesting that investors view insurance stocks as having low market risk. Ammar, Eling and Milidonis (2014) study the cross sectional returns of financial institutions and report similar results for the traditional CAPM betas for the US publicly-traded life insurers. However, the estimation results for Models II and III show that market downside risk is both a statistically and economically significant pricing factor for life insurance stocks. Without including the liquidity control, the downside risk premium is $15.4 \%$ and the upside risk premium is $-8.6 \%$. Although the liquidity beta coefficient is not statistically significant in Model III, adding this control variable increases the downside risk premium to $16.9 \%$ and takes away the significance of upside risk. Larger firms and those with greater volatility are associated with lower average returns. 
Higher-order co-moments matter to risk-averse investors concerned about extreme outcomes. The average coskewness premium is positive and highly significant over the period. Additionally, consistent with findings in previous studies (Chung, Johnson and Schill, 2006; Nguyen and Puri, 2009), the Fama-French SMB and HML factor loadings are less significant pricing factors when higher-order systematic co-moments are included in cross-sectional regressions. This suggests that the Fama-French factors proxy for higher-order co-moments.

Because stock price movements were highly correlated during and after the financial crisis, a period of significant downside risk, we separately estimate the model for the sub-period 1990 to 2006 as a robustness check. Comparing the full sample period and the sub-sample period results in Table 3, we find that downside risk is a priced factor for both the shorter and longer periods, although the premium to downside risk was slightly larger in the earlier period of our sample. Although upside risk is a negative risk factor $(-9.3 \%)$ in Model III for the pre-financial crisis period it is insignificant for the full period. Consistent with our findings for the full sample period, traditional CAPM beta was not a significant factor in insurance company returns prior to the financial crisis. Based on this analysis, we conclude that the magnitude of the downside risk premium for life insurers is not simply the result of unusual factors associated with the financial crisis.

\subsection{Cross-sectional regressions with industry-specific controls for size and leverage}

The left side of Table 4 presents the regression results substituting the insurance size and leverage controls. For the full data period (1990-2012), we see somewhat different results using the insurer-specific controls in place of the traditional measures of size and leverage reported in Table 3. As with the traditional controls, downside beta in Model III has a positive risk premium $(16.8 \%)$, upside risk is not a significant factor, and momentum has a negative effect on returns. After substituting insurer-specific controls, we find that size, volatility, and coskewness are no longer significant risk factors, whereas greater insurer leverage results in a lower cost of equity.

[Insert Table 4 Here]

As in the previous section, we separately analyze the pre-financial crisis period as a robustness check. The right side of Table 4 reports the results of cross-sectional regressions using insurer-specific controls for the period (1990-2006). In all versions of the model, downside 
risk is associated with a positive and significant risk premium. Comparing the Model III results reported in this table with the corresponding Model in Table 3 that used traditional measures of leverage and size, the positive risk premium on downside risk is slightly lower $(16.7 \%$ versus $19.6 \%$ with the traditional controls) and upside risk has a larger negative effect (-17.0\% versus $9.3 \%$ with traditional controls).

Notably, regardless of our model specification, we find much larger downside risk premia for life insurers than has been reported elsewhere for the broad cross-section of stocks. Comparing the full sample to the period 1990-2006 reveals that the inclusion of the financial crisis period slightly reduces the reward to downside risk. Although the downside risk premium is large and significant in all our specifications, the coefficient estimates in the pre-financial crisis period are all slightly lower than the estimate for the full sample period. Because the financial crisis was a period in which all firms exhibited greater market risk, investors may have been less able to distinguish between the upside and downside risk.

Comparing the signs and significance of the other control variables for the models with traditional versus insurance controls, we find some important differences. Although the coefficient estimates for coskewness are positive in both models, the model with insurer-specific controls shows a significant negative effect for momentum and leverage and a positive effect for cokurtosis. We find that when size is measured as the log of market capitalization, it carries a negative risk premium, whereas the premium is positive when size is measured as the $\log$ of book value as the insurer-specific size control.

\subsection{Comparison of results for life insurers and property and casualty insurers}

The fact that life insurance investors require a larger premium for downside risk is consistent with expectations based on characteristics of these firms. However, it is reasonable to ask whether this result holds for other types of insurers as well. Although life insurers do have some similarities to $\mathrm{P} \& \mathrm{C}$ insurers, their asset and liability portfolios are substantially different. The longer terms of life insurance contracts, such as permanent life insurance policies and annuities, generally result in higher leverage and greater interest-rate sensitivity (Cummins and Outreville, 1987; Fung, Lai, Patterson and Witt, 1998; Cummins and Phillips, 2005). Life insurer asset portfolios are primarily invested in medium- and longer-term fixed income investments, 
whereas $\mathrm{P} \& \mathrm{C}$ insurer portfolios include more diversified mix of liquid investments, with larger allocations to risky assets, including equities (Rejda, 2014). Furthermore, the P\&C industry is exposed to unique underwriting cycle effects that do not coincide with market-wide systematic risk effects. Therefore, we expect that $\mathrm{P} \& \mathrm{C}$ insurers realized equity returns will include a smaller premium for bearing downside risk as compared to life insurers.

[Insert Table 5-6 Here]

We estimate similar cross-sectional regressions for property and casualty insurers with both traditional equity controls and with industry-specific controls. The results reported in Tables 5 and 6 show that $P \& C$ insurers are more similar to the broad cross-section of stocks, exhibiting a much smaller downside risk premium (7\% with the traditional controls and $9 \%$ with the industry-specific controls). Notably, the traditional CAPM beta is a significant factor in P\&C insurance company returns. The results also show a significant negative effect for momentum, volatility and cokurtosis. As in the previous section, we separately analyze the pre-financial crisis period as a robustness check and show that downside risk is associated with a positive and significant risk premium with similar magnitude in all versions of the model. These results provide further support for the uniqueness of the life insurance industry with respect to downside risk effects.

\section{CONCLUSIONS}

We examine the impact of downside risk on life insurer returns and the cost of equity. Using Fama and MacBeth cross-sectional regressions, we conclude that downside risk is an economically and statistically significant pricing factor and that higher downside risk is associated with higher returns to life insurer investors for the period of 1990 to 2012. A positive downside risk premium is consistent with results for the broader cross-section of stocks, but we find that the magnitude of the effect is much greater for life insurance stocks. The cross-section of life insurer returns reflects a downside risk premium of $16.9 \%$ per year, which is nearly three times the $6 \%$ premium found for the broad cross-section of stocks. Furthermore, consistent with the literature for the general stock market, we find that the traditional CAPM beta is not a significant pricing factor. 
The usual explanation for the pricing of downside risk is that loss aversion causes utilitymaximizing investors to place greater weight on the disutility of potential losses relative to the positive utility from potential gains. Given the life insurance industry's unique role in providing long-term protection to U.S. households and the relative important of market returns to firm performance in this industry, investors may attach greater weight to this risk factor than they do for stocks at large. A second possible explanation for the greater reward to downside risk is that life insurance company stockholders view this sector as a defensive play and thus would prefer to invest in firms with lower downside risk, all else equal.

Overall, this study contributes to the growing literature on life insurer cost of equity by introducing a new and highly significant pricing factor. By estimating the cost of life insurer equity capital conditional on its upside and downside risks with the broader equity market, and controlling for specific life insurer characteristics and risk factors, we provide an improved model for estimating the associated cost of equity. These results have implications for investors and analysts interested in specific equity sectors in that they suggest that a general model may not be appropriate for all sectors. 


\section{References}

Ammar S. B., M. Eling, and A. Milidonis, 2014. Asset Pricing of Financial Institutions: the cross-section of expected insurance stock returns. Working paper.

Ané, T., and H. Geman, 2000. Order flow, transaction clock, and normality of asset returns, The Journal of Finance 55(5), 2259-2284.

Ang, A., J. Chen, and Y. Xing, 2006. Downside risk, Review of Financial Studies 19(4), 1191 1239.

Aspara, J., 2013. The role of product and brand perceptions in stock investing, effects on investment considerations, optimism and confidence, Journal of Behavioral Finance 14(3), 195-212.

Banz, R. W., 1981. The relationship between return and market value of common stocks, Journal of Financial Economics 9(1), 3-18.

Barberis, N., and M. Huang, 2001. Mental accounting, loss aversion, and individual stock returns, The Journal of Finance 56(4), 1247-1292.

Basu, S., 1983. The relationship between earnings' yield, market value and return for NYSE common stocks: Further evidence, Journal of Financial Economics 12(1), 129-156.

Bawa, V. S., and E. B. Lindenberg, 1977. Capital market equilibrium in a mean-lower partial moment framework, Journal of Financial Economics 5(2), 189-200.

Benishay, H., 1992. The Pratt-Arrow requirement in a fourth degree polynomial utility function. Journal of Accounting, Auditing and Finance 7(1), 97-112.

Browne, M. J., J. M. Carson, and R. E. Hoyt, 2001. Dynamic financial models of life insurers, North American Actuarial Journal 5(2), 11-26.

Campbell, J. Y., and T. Vuolteenaho, 2004. Bad beta, good beta, American Economic Review 94(5), 1249-1275.

Chen, H., J. D. Cummins, K. S. Viswanathan, and M. A. Weiss, 2014. Systemic risk and the interconnectedness between banks and insurers: An econometric analysis, Journal of Risk and Insurance 81(3), 623-652.

Chen, F., X. Chen, Z. Sun, T. Yu, and M. Zhong, 2013. Systemic risk, financial crisis, and credit risk insurance, The Financial Review 48(3), 417-442.

Chung, Y. P., H. Johnson, and M. J. Schill, 2006. Asset pricing when returns are nonnormal: Fama-French factors versus higher order systematic comoments, The Journal of Business 79(2), 923-940.

Cummins, J. D., and J. F. Outreville, 1987. An international analysis of underwriting cycles in property-liability insurance, Journal of Risk and Insurance 54(2), 246-262.

Cummins, J. D., and R. D. Phillips, 2005. Estimating the cost of equity capital for propertyliability insurers, Journal of Risk and Insurance 72(3), 441-478. 
Cummins, J. D., and R. D. Phillips, 2009, Capital adequacy and insurance risk-based capital systems, Journal of Insurance Regulation 28(1), 25-72.

Cummins, J. D., and M. A. Weiss, 2014. Systemic risk and the US insurance sector, Journal of Risk and Insurance 81(3), 489-528.

Dittmar, R. F. 2002. Nonlinear pricing kernels, kurtosis preference, and evidence from the cross section of equity returns, Journal of Finance 57(1), 369-403.

Fama, E. F., and K. R. French, 1992. The cross-section of expected stock returns, Journal of Finance 47(2), 427-465.

Fama, E. F., and K. R. French, 1993. Common risk factors in the returns on stocks and bonds, Journal of Financial Economics 33(1), 3-56.

Fama, E. F., and K. R. French, 1996. Multifactor explanations of asset pricing anomalies, Journal of Finance 51(1), 55-84.

Fama, E. F., and J. D. MacBeth, 1973. Risk, return, and equilibrium: empirical tests, Journal of Political Economy 71, 607-636.

Fang, H., and T. Y. Lai, 1997. Cokurtosis and capital asset pricing. Financial Review 32(2), 293307.

Fung, H. G., G. C. Lai, G. A. Patterson, and R. C. Witt, 1998. Underwriting cycles in property and liability insurance: an empirical analysis of industry and by-line data, Journal of Risk and Insurance 65(4), 539-561.

Grace, M. F., 2010. The insurance industry and systemic risk: Evidence and discussion, Networks Financial Institute Policy Brief, 2010-PB: 02.

Gooding, A. E., 1976. Some preliminary findings regarding the nature of investment risk, Financial Review 11(1), 21-35.

Gul, F., 1991. A theory of disappointment aversion, Econometrica 59, 667-686.

Halek, M., and D. L. Eckles, 2010. Effects of analyst's ratings on insurer stock returns: evidence of asymmetric responses, Journal of Risk and Insurance 77(4), 801-827.

Harvey, C. R., and A. Siddique, 2000. Conditional skewness in asset pricing tests, Journal of Finance 55(3), 1263-1295.

Harrington, S. E., 2009. The financial crisis, systemic risk, and the future of insurance regulation, Journal of Risk and Insurance 76(4), 785-819.

Jegadeesh, N., and S. Titman, 1993. Returns to buying winners and selling losers: implications for stock market efficiency, Journal of Finance 48(1), 65-91.Kahneman, D., and A. Tversky, 1979. Prospect theory: An analysis of decision under risk, Econometrica 47, 263-291.

Kim, M. K., and J. K. Zumwalt, 1979. An analysis of risk in bull and bear markets, Journal of Financial and Quantitative Analysis 14(5), 1015-1025.

Kothari, S. P., J. Shanken, and R. G. Sloan, 1995. Another look at the cross-section of expected stock returns, Journal of Finance 50(1), 185-224. 
Lambert, M., and G.Hübner, 2013. Comoment risk and stock returns, Journal of Empirical Finance 23, 191-205.

Liebenberg, A. P., J. M. Carson, and R. E. Dumm, 2012. A dynamic analysis of the demand for life insurance, Journal of Risk and Insurance 79(3), 619-644.

Lintner, J., 1965. The valuation of risk assets and the selection of risky investments in stock portfolios and capital budgets, Review of Economic Statistics 47(1), 13-37.

Markowitz, H., 1959. Portfolio Selection, Yale University Press, New Haven, CT.

Maurice Tse, K. S., J. Uppal, and M. A. White, 1993. Downside risk and investment choice, The Financial Review 28(4), 585-605.

Miao, H., S. Ramchander, and T. Wang, 2014. The Response of Bond Prices to Insurer Ratings Changes, The Geneva Papers on Risk and Insurance-Issues and Practice 39(2), 389-413.

Mossin, J., 1966. Equilibrium in a capital asset market, Econometrica 34(4), 768-783.

Newey, W. K., and K. D. West, 1987. A simple, positive semi-definite, heteroskedasticity and autocorrelation consistent covariance matrix, Econometrica 55, 7038.

Nguyen, D., and T. N. Puri, 2009. Higher-order systematic comoments and asset pricing: new evidence, The Financial Review 44(3), 345369.

Nissim, D., 2013. Implied cost of equity capital in the US insurance industry, Journal of Financial Perspectives 1-17.

Pástor, L., and R. F. Stambaugh, 2003. Liquidity risk and expected stock returns, Journal of Political Economy 111, 642-685.

Rejda, G. and M. McNamara, 2014. Principles of Risk Management and Insurance, 12th edition. (Pearson. MA).

Roy, A. D., 1952. Safety first and the holding of assets, Econometrica 20, 431-449.

Rubinstein, M., 1973. The fundamental theorem of parameter-preference security valuation, Journal of Financial and Quantitative Analysis 8(1), 61-69.

Scott, R. C., and P. A. Horvath, 1980. On the direction of preference for moments of higher order than the variance, Journal of Finance 35(4), 915-919.

Solt, M. E., and M. Statman, 1989. Good companies, bad stocks, Journal of Portfolio Management 15(4), 39-44.

Sharpe, W. F., 1964. Capital asset prices: A theory of market equilibrium under conditions of risk, Journal of Finance 19(3), 425-42.

Wen, M. M., A. D. Martin, G. Lai, and T. J. O'Brien, 2008. Estimating the cost of equity for property-liability insurance companies, Journal of Risk and Insurance 75(1), 101-124.

You, L., and R. T. Daigler, 2010. Using four-moment tail risk to examine financial and commodity instrument diversification, The Financial Review 45, 11011123. 


\section{Table 1}

\section{Descriptive statistics, publicly-traded life insurers, 1990-2012}

The table reports summary statistics for publicly-traded life insurers based on stock price data from the Center for Research in Securities Prices (CRSP) and firm financial data from COMPUSTAT. Leverage $=($ Book Value of Assets - Book Value of Equity)/Book Value of Asset; Book-to-Market = Book Value of Assets/Market Capitalization; Momentum $=$ Stock return for past twelve months; realized risk characteristics including betas, Volatility (standard deviation), coskewness and cokurtosis are calculated over the following twelve-month period using daily continuous compounded returns; Liquidity Beta $=$ historical liquidity betas as in Pástor and Stambaugh (2003).

\begin{tabular}{llllllll}
\hline & Mean & Median & Std. Dev. & Min & Max & $1^{\text {st }}$ Pctl & $99^{\text {th }}$ Pctl \\
\hline Realized Return & 0.012 & 0.007 & 0.110 & -0.726 & 1.509 & -0.280 & 0.338 \\
CAPM $\beta$ & 0.837 & 0.748 & 0.669 & -9.341 & 5.902 & -0.226 & 3.096 \\
Downside Beta $\beta^{-}$ & 0.896 & 0.817 & 0.700 & -1.712 & 7.722 & -0.633 & 3.059 \\
Upside Beta $\beta^{+}$ & 0.800 & 0.739 & 0.895 & -20.608 & 9.431 & -1.045 & 3.429 \\
Ln(Market Capitalization) & 20.559 & 20.730 & 1.561 & 15.239 & 24.578 & 16.677 & 24.011 \\
Ln(Book Value of Assets) & 22.929 & 22.758 & 2.252 & 17.704 & 28.282 & 18.084 & 28.135 \\
Leverage & 0.847 & 0.863 & 0.101 & 0.485 & 1.839 & 0.588 & 0.981 \\
Book-to-Market & 1.072 & 0.880 & 0.899 & -1.992 & 20.764 & 0.166 & 4.244 \\
Momentum & 0.096 & 0.072 & 0.437 & -0.963 & 12.173 & -0.758 & 1.122 \\
Volatility & 0.024 & 0.020 & 0.016 & 0.002 & 0.172 & 0.008 & 0.092 \\
Coskewness & -0.106 & -0.093 & 0.220 & -1.415 & 0.854 & -0.732 & 0.382 \\
Cokurtosis & 1.868 & 1.616 & 1.485 & -3.245 & 9.834 & -0.635 & 6.521 \\
Liquidity Beta $\beta^{\mathrm{L}}$ & -0.009 & -0.034 & 2.615 & -31.641 & 181.100 & -1.241 & 1.096 \\
\hline
\end{tabular}




\section{Table 2}

\section{Returns of stock portfolios sorted by realized betas}

This table lists the equal-weighted average returns and risk characteristics of stocks sorted by realized betas. For each month between 1990 and 2012, we calculate $\beta, \beta^{+}$, and $\beta^{-}$with respect to the market using daily continuously compounded returns over the next twelve months. For each risk characteristic, we rank all publicly-traded life insurers and sort them into terciles. The column labeled "Return" reports the average returns in excess of the onemonth treasury-bill rate over the contemporaneous twelve months. The column labeled " $\beta$ ", " $\beta^{+}$", and " $\beta$ "” report the time series and cross-sectional average of CAPM beta, upside beta and downside beta for the terciles. The row labeled "High-Low" reports the difference between the highest and lowest terciles. The entry labeled " $t$-test" reports the $t$-statistics computed using Newey-West (1987) heteroskedastic-robust standard errors for the High-Low difference.

\begin{tabular}{llllll}
\hline Panel A: Stocks sorted by realized $\beta$ (1990-2012) & & & & \\
\hline Portfolio & Return & $\beta$ & $\beta^{-}$ & $\beta^{+}$ \\
1 Low $\beta$ & $10.53 \%$ & 0.446 & 0.508 & 0.358 \\
2 & $11.96 \%$ & 0.871 & 0.891 & 0.864 \\
3 High $\beta$ & $16.95 \%$ & 1.430 & 1.444 & 1.478 \\
High - Low & $6.42 \% * *$ & 0.984 & 0.936 & 1.120 \\
t-stat & 2.350 & & & \\
\hline Panel B: Stocks sorted by realized $\beta^{+}(1990-2012)$ & & & & \\
\hline Portfolio & & & & \\
1 Low $\beta+$ & Return & $\beta$ & $\beta^{-}$ & $\beta^{+}$ \\
2 & $10.02 \%$ & 0.520 & 0.618 & 0.269 \\
3 High $\beta+$ & $12.34 \%$ & 0.874 & 0.905 & 0.856 \\
High - Low & $17.25 \%$ & 1.356 & 1.322 & 1.573 \\
t-stat & $7.22 \% * * *$ & 0.836 & 0.705 & 1.304 \\
\hline Panel C: Stocks sorted by realized $\beta$ & $(1990-2012)$ & 3.080 & & & \\
\hline Portfolio & & & & \\
\hline Low $\beta$ - & Return & $\beta$ & $\beta^{-}$ & $\beta^{+}$ \\
2 & $9.82 \%$ & 0.521 & 0.397 & 0.507 \\
3 High $\beta$ - & $11.64 \%$ & 0.881 & 0.916 & 0.877 \\
High - Low & $18.00 \%$ & 1.348 & 1.524 & 1.323 \\
t-stat & $8.18 \% * * *$ & 0.827 & 1.127 & 0.816 \\
\hline
\end{tabular}

$* * *, * *, *$ indicate statistical significance at $0.01,0.05$ and 0.1 level, respectively. 
Table 3

\section{Life Insurers Fama-MacBeth Regressions, 1990-2012 vs 1990-2006}

This table shows the results of Fama-MacBeth (1973) regressions of overlapping 12-month excess returns on firm characteristics and realized risk characteristics. The sample period is from January 1990 to December 2012 for the full sample period on the left and from January 1990 to December 2006 for the sub-sample period on the right. Observations are at a monthly frequency for all publicly-traded life insurance companies. The $t$-statistics computed using Newey-West (1987) heteroskedastic-robust standard errors are reported in parentheses. Realized risk characteristics and other controls are defined in Table 1. All independent variables are winsorized at the $1 \%$ level and at the $99 \%$ level within each quarter. The last column reports time-series averages of the cross-sectional mean and standard deviation (in parentheses) of each independent variable.

\begin{tabular}{|c|c|c|c|c|c|c|c|c|}
\hline & \multicolumn{4}{|c|}{ Full Sample Period: 1990-2012 } & \multicolumn{4}{|c|}{ Sub-Sample Period: 1990-2006 } \\
\hline $\begin{array}{l}\text { Model } \\
\text { Control Variable }\end{array}$ & $\mathrm{I}$ & II & III & $\begin{array}{c}\text { Mean } \\
\text { (Std.Dev.) }\end{array}$ & $\mathrm{I}$ & II & III & $\begin{array}{c}\text { Mean } \\
\text { (Std.Dev.) }\end{array}$ \\
\hline Intercept & $\begin{array}{c}0.869 * * * \\
(4.77)\end{array}$ & $\begin{array}{c}0.707 * * * \\
\quad(4.12)\end{array}$ & $\begin{array}{c}0.543 * * * \\
(3.11)\end{array}$ & & $\begin{array}{c}1.109^{* * *} \\
(6.52)\end{array}$ & $\begin{array}{c}0.963 * * * \\
(5.73)\end{array}$ & $\begin{array}{c}0.806 * * * \\
(4.72)\end{array}$ & \\
\hline CAPM $\beta$ & $\begin{array}{c}0.03 \\
(0.76)\end{array}$ & & & $\begin{array}{c}0.861 \\
(0.658)\end{array}$ & $\begin{array}{c}0.05 \\
(1.13)\end{array}$ & & & $\begin{array}{c}0.682 \\
(0.488)\end{array}$ \\
\hline Downside $\beta^{-}$ & & $\begin{array}{c}0.154 * * * \\
(2.62)\end{array}$ & $\begin{array}{c}0.169 * * \\
(2.44)\end{array}$ & $\begin{array}{c}0.900 \\
(0.677)\end{array}$ & & $\begin{array}{c}0.167 * * * \\
(4.15)\end{array}$ & $\begin{array}{c}0.196^{* * * *} \\
(4.30)\end{array}$ & $\begin{array}{l}0.750 \\
(0.57)\end{array}$ \\
\hline Upside $\beta^{+}$ & & $\begin{array}{c}-0.086^{*} \\
(1.78)\end{array}$ & $\begin{array}{l}-0.079 \\
(1.52)\end{array}$ & $\begin{array}{c}0.858 \\
(0.869)\end{array}$ & & $\begin{array}{c}-0.112^{* *} \\
(2.45)\end{array}$ & $\begin{array}{c}-0.093 * * \\
(1.99)\end{array}$ & $\begin{array}{c}0.655 \\
(0.699)\end{array}$ \\
\hline Ln(Mkt Cap) & $\begin{array}{c}-0.036^{* * *} \\
(4.22)\end{array}$ & $\begin{array}{c}-0.023 * * \\
(2.33)\end{array}$ & $\begin{array}{c}-0.017 * \\
(1.76)\end{array}$ & $\begin{array}{l}20.559 \\
(1.561)\end{array}$ & $\begin{array}{c}-0.046^{* * *} \\
(6.52)\end{array}$ & $\begin{array}{c}-0.039 * * * \\
(5.37)\end{array}$ & $\begin{array}{c}-0.032 * * * \\
(4.39)\end{array}$ & $\begin{array}{l}20.367 \\
(1.562)\end{array}$ \\
\hline Book-to-Market & $\begin{array}{l}0.001 \\
(0.03)\end{array}$ & $\begin{array}{l}-0.004 \\
(0.21)\end{array}$ & $\begin{array}{l}0.000 \\
(0.01)\end{array}$ & $\begin{array}{c}1.072 \\
(0.898)\end{array}$ & $\begin{array}{l}-0.018 \\
(0.76)\end{array}$ & $\begin{array}{l}-0.029 \\
(1.24)\end{array}$ & $\begin{array}{l}-0.019 \\
(0.81)\end{array}$ & $\begin{array}{c}0.902 \\
(0.464)\end{array}$ \\
\hline Momentum & $\begin{array}{c}-0.094 * * \\
(2.20)\end{array}$ & $\begin{array}{l}-0.069 \\
(1.59)\end{array}$ & $\begin{array}{c}-0.074 * \\
(1.67)\end{array}$ & $\begin{array}{c}0.096 \\
(0.437)\end{array}$ & $\begin{array}{c}-0.083^{* *} \\
(2.38)\end{array}$ & $\begin{array}{c}-0.071^{*} \\
(1.81)\end{array}$ & $\begin{array}{l}-0.05 \\
(1.23)\end{array}$ & $\begin{array}{c}0.113 \\
(0.312)\end{array}$ \\
\hline Volatility & $\begin{array}{c}-6.270 * * * \\
(3.18)\end{array}$ & $\begin{array}{c}-6.729 * * \\
(-2.18)\end{array}$ & $\begin{array}{l}-5.684^{*} \\
(-1.89)\end{array}$ & $\begin{array}{c}0.024 \\
(0.016)\end{array}$ & $\begin{array}{c}-6.480 * * * \\
(3.12)\end{array}$ & $\begin{array}{c}-5.573 * * * \\
(2.92)\end{array}$ & $\begin{array}{c}-5.818 * * * \\
(3.19)\end{array}$ & $\begin{array}{c}0.021 \\
(0.009)\end{array}$ \\
\hline Coskewness & $\begin{array}{l}0.131^{*} \\
(1.74)\end{array}$ & $\begin{array}{c}0.497 * * * \\
(3.72)\end{array}$ & $\begin{array}{c}0.479 * * * \\
(2.89)\end{array}$ & $\begin{array}{l}-0.090 \\
(0.207)\end{array}$ & $\begin{array}{l}-0.009 \\
(0.16)\end{array}$ & $\begin{array}{c}0.388 * * * \\
(3.39)\end{array}$ & $\begin{array}{c}0.350 * * \\
(2.46)\end{array}$ & $\begin{array}{l}-0.096 \\
(0.204)\end{array}$ \\
\hline Cokurtosis & $\begin{array}{l}0.015 \\
(0.70)\end{array}$ & $\begin{array}{l}0.001 \\
(0.02)\end{array}$ & $\begin{array}{l}-0.009 \\
(0.24)\end{array}$ & $\begin{array}{l}1.879 \\
(1.431)\end{array}$ & $\begin{array}{l}0.016 \\
(0.90)\end{array}$ & $\begin{array}{c}0.044 * * \\
(2.00)\end{array}$ & $\begin{array}{l}0.024 \\
(0.97)\end{array}$ & $\begin{array}{c}1.521 \\
(1.166)\end{array}$ \\
\hline Liquidity Beta & & & $\begin{array}{l}-0.009 \\
(0.25) \\
\end{array}$ & $\begin{array}{l}-0.039 \\
(0.874)\end{array}$ & & & $\begin{array}{l}0.001 \\
(0.03) \\
\end{array}$ & $\begin{array}{l}-0.024 \\
(0.957)\end{array}$ \\
\hline $\begin{array}{l}\text { Mean Adjust } \mathrm{R}^{2} \\
\text { F-statistics }\end{array}$ & $\begin{array}{c}0.254 * * * \\
(9.98)\end{array}$ & $\begin{array}{c}0.299 * * * \\
(11.43)\end{array}$ & $\begin{array}{c}0.337 * * * \\
(12.65)\end{array}$ & & $\begin{array}{c}0.211 * * * \\
(8.32)\end{array}$ & $\begin{array}{c}0.237 * * * \\
(8.91)\end{array}$ & $\begin{array}{c}0.267 * * * \\
(9.50)\end{array}$ & \\
\hline
\end{tabular}

$* * *, * * *$ indicate statistical significance at $0.01,0.05$ and 0.1 level, respectively. 
Table 4

\section{Life Insurers Fama-MacBeth Regressions (Insurers Controls), 1990-2012 vs 1990-2006}

This table shows the results of Fama-MacBeth (1973) regressions of overlapping 12-month excess returns on specific insurance firm characteristics and realized risk characteristics. The sample period is from January 1990 to December 2012 for the full sample period on the left and from January 1990 to December 2006 for the sub-sample period on the right. Observations are at a monthly frequency for all publicly-traded life insurance companies. The $t$-statistics computed using Newey-West (1987) heteroskedastic-robust standard errors are reported in parentheses. Realized risk characteristics and life insurance controls are defined in Table 1. All independent variables are winsorized at the $1 \%$ level and at the $99 \%$ level within each quarter. The last column reports time-series averages of the cross-sectional mean and standard deviation (in parentheses) of each independent variable.

\begin{tabular}{|c|c|c|c|c|c|c|c|c|}
\hline & \multicolumn{4}{|c|}{ Full Sample Period: 1990-2012 } & \multicolumn{4}{|c|}{ Sub-Sample Period: 1990-2006 } \\
\hline $\begin{array}{l}\text { Model } \\
\text { Control Variable }\end{array}$ & I & II & III & $\begin{array}{c}\text { Mean } \\
\text { (Std.Dev.) }\end{array}$ & I & II & III & $\begin{array}{c}\text { Mean } \\
\text { (Std.Dev.) }\end{array}$ \\
\hline Intercept & $\begin{array}{l}0.501 * * \\
(2.49)\end{array}$ & $\begin{array}{c}0.615^{* *} \\
(2.01)\end{array}$ & $\begin{array}{l}0.527 * \\
(1.71)\end{array}$ & & $\begin{array}{l}-0.012 \\
(0.08)\end{array}$ & $\begin{array}{l}-0.026 \\
(0.16)\end{array}$ & $\begin{array}{l}-0.128 \\
(0.73)\end{array}$ & \\
\hline CAPM $\beta$ & $\begin{array}{l}0.035 \\
(0.83)\end{array}$ & & & $\begin{array}{c}0.861 \\
(0.658)\end{array}$ & $\begin{array}{l}-0.035 \\
(-0.84)\end{array}$ & & & $\begin{array}{c}0.682 \\
(0.488)\end{array}$ \\
\hline Downside $\beta^{-}$ & & $\begin{array}{c}0.166^{* * * *} \\
(3.08)\end{array}$ & $\begin{array}{l}0.168 * * * \\
(2.67)\end{array}$ & $\begin{array}{c}0.900 \\
(0.677)\end{array}$ & & $\begin{array}{c}0.157 * * * \\
(3.57)\end{array}$ & $\begin{array}{c}0.167 * * * \\
(3.62)\end{array}$ & $\begin{array}{l}0.750 \\
(0.57)\end{array}$ \\
\hline Upside $\beta^{+}$ & & $\begin{array}{l}-0.096 \\
(1.44)\end{array}$ & $\begin{array}{c}-0.052 \\
(0.70)\end{array}$ & $\begin{array}{c}0.858 \\
(0.869)\end{array}$ & & $\begin{array}{c}-0.205^{* * *} \\
(4.34)\end{array}$ & $\begin{array}{c}-0.170^{* * *} \\
(3.51)\end{array}$ & $\begin{array}{c}0.655 \\
(0.699)\end{array}$ \\
\hline $\operatorname{Ln}(\mathrm{BV})$ & $\begin{array}{l}-0.002 \\
(0.28)\end{array}$ & $\begin{array}{l}0.006 \\
(0.88)\end{array}$ & $\begin{array}{c}0.01 \\
(1.45)\end{array}$ & $\begin{array}{l}20.559 \\
(1.561)\end{array}$ & $\begin{array}{l}0.010^{*} \\
(1.78)\end{array}$ & $\begin{array}{c}0.01 \\
(1.54)\end{array}$ & $\begin{array}{l}0.014^{*} \\
(1.92)\end{array}$ & $\begin{array}{l}20.367 \\
(1.562)\end{array}$ \\
\hline Leverage & $\begin{array}{c}-0.457 * * \\
(2.10)\end{array}$ & $\begin{array}{c}-0.654 * * * \\
(2.63)\end{array}$ & $\begin{array}{c}-0.610 * * * \\
(2.72)\end{array}$ & $\begin{array}{c}1.072 \\
(0.898)\end{array}$ & $\begin{array}{c}-0.182 * * \\
(2.23)\end{array}$ & $\begin{array}{c}-0.246^{* * *} \\
(2.87)\end{array}$ & $\begin{array}{c}-0.205^{* *} \\
(2.46)\end{array}$ & $\begin{array}{c}0.902 \\
(0.464)\end{array}$ \\
\hline Momentum & $\begin{array}{c}-0.275^{* * * *} \\
(2.88)\end{array}$ & $\begin{array}{c}-0.266^{* *} \\
(2.54)\end{array}$ & $\begin{array}{c}-0.266^{* * * *} \\
(2.70)\end{array}$ & $\begin{array}{c}0.096 \\
(0.437)\end{array}$ & $\begin{array}{c}-0.134 * * * \\
(4.00)\end{array}$ & $\begin{array}{c}-0.119 * * * \\
(3.14)\end{array}$ & $\begin{array}{c}-0.112 * * * \\
(2.98)\end{array}$ & $\begin{array}{c}0.113 \\
(0.312)\end{array}$ \\
\hline Volatility & $\begin{array}{l}-2.537 \\
(1.31)\end{array}$ & $\begin{array}{l}-1.525 \\
(0.46)\end{array}$ & $\begin{array}{l}-2.323 \\
(0.71)\end{array}$ & $\begin{array}{c}0.024 \\
(0.016)\end{array}$ & $\begin{array}{l}0.721 \\
(0.39)\end{array}$ & $\begin{array}{c}4.536^{*} \\
(1.92)\end{array}$ & $\begin{array}{l}3.661^{*} \\
(1.66)\end{array}$ & $\begin{array}{c}0.021 \\
(0.009)\end{array}$ \\
\hline Coskewness & $\begin{array}{l}-0.014 \\
(0.18)\end{array}$ & $\begin{array}{c}0.388^{* *} \\
(2.16)\end{array}$ & $\begin{array}{l}0.318 \\
(1.51)\end{array}$ & $\begin{array}{l}-0.090 \\
(0.207)\end{array}$ & $\begin{array}{c}-0.114^{*} \\
(1.78)\end{array}$ & $\begin{array}{c}0.445 * * * \\
(3.35)\end{array}$ & $\begin{array}{c}0.375^{* *} \\
(2.49)\end{array}$ & $\begin{array}{l}-0.096 \\
(0.204)\end{array}$ \\
\hline Cokurtosis & $\begin{array}{l}-0.003 \\
(0.10)\end{array}$ & $\begin{array}{l}-0.044 \\
(0.69)\end{array}$ & $\begin{array}{l}-0.073 \\
(1.09)\end{array}$ & $\begin{array}{c}1.879 \\
(1.431)\end{array}$ & $\begin{array}{c}0.032^{*} \\
(1.78)\end{array}$ & $\begin{array}{c}0.065 * * * \\
(2.89)\end{array}$ & $\begin{array}{l}0.044^{*} \\
(1.85)\end{array}$ & $\begin{array}{c}1.521 \\
(1.166)\end{array}$ \\
\hline Liquidity Beta & & & $\begin{array}{l}-0.022 \\
(0.61)\end{array}$ & $\begin{array}{l}-0.039 \\
(0.874)\end{array}$ & & & $\begin{array}{l}-0.005 \\
(0.14)\end{array}$ & $\begin{array}{c}-0.024 \\
(0.957)\end{array}$ \\
\hline $\begin{array}{l}\text { Mean Adjust R }{ }^{2} \\
\text { F-statistics }\end{array}$ & $\begin{array}{c}0.247 * * * \\
(9.62)\end{array}$ & $\begin{array}{c}0.304 * * * \\
(11.70)\end{array}$ & $\begin{array}{c}0.327 * * * \\
(12.52)\end{array}$ & & $\begin{array}{c}0.208 * * * \\
(7.93)\end{array}$ & $\begin{array}{c}0.262 * * * \\
(9.63)\end{array}$ & $\begin{array}{c}0.281^{* * *} \\
(10.00)\end{array}$ & \\
\hline
\end{tabular}

$* * *, * *, *$ indicate statistical significance at $0.01,0.05$ and 0.1 level, respectively. 
Table 5

\section{P\&C Insurers Fama-MacBeth Regressions, 1990-2012 vs 1990-2006}

This table shows the results of Fama-MacBeth (1973) regressions of overlapping 12-month excess returns on firm characteristics and realized risk characteristics. The sample period is from January 1990 to December 2012 for the full sample period on the left and from January 1990 to December 2006 for the sub-sample period on the right. Observations are at a monthly frequency for all publicly-traded P\&C insurance companies. The $t$-statistics computed using Newey-West (1987) heteroskedastic-robust standard errors are reported in parentheses. Realized risk characteristics and other controls are defined in Table 1. All independent variables are winsorized at the 1\% level and at the $99 \%$ level within each quarter. The last column reports time-series averages of the cross-sectional mean and standard deviation (in parentheses) of each independent variable.

\begin{tabular}{|c|c|c|c|c|c|c|c|c|}
\hline & \multicolumn{4}{|c|}{ Full Sample Period: 1990-2012 } & \multicolumn{4}{|c|}{ Sub-Sample Period: 1990-2006 } \\
\hline $\begin{array}{l}\text { Model } \\
\text { Control Variable }\end{array}$ & I & II & III & $\begin{array}{c}\text { Mean } \\
\text { (Std.Dev.) }\end{array}$ & $\mathrm{I}$ & II & III & $\begin{array}{c}\text { Mean } \\
\text { (Std.Dev.) }\end{array}$ \\
\hline Intercept & $\begin{array}{c}0.143 \\
(0.164)\end{array}$ & $\begin{array}{c}0.108 \\
(0.162)\end{array}$ & $\begin{array}{c}0.108 \\
(0.162)\end{array}$ & & $\begin{array}{l}0.409 * * \\
(0.203)\end{array}$ & $\begin{array}{l}0.342^{*} \\
(0.203)\end{array}$ & $\begin{array}{l}0.344^{*} \\
(0.204)\end{array}$ & \\
\hline CAPM $\beta$ & $\begin{array}{c}0.104 * * * \\
(0.036)\end{array}$ & & & $\begin{array}{c}0.763 \\
(0.422)\end{array}$ & $\begin{array}{c}0.165 * * * \\
(0.043)\end{array}$ & & & $\begin{array}{c}0.675 \\
(0.393)\end{array}$ \\
\hline Downside $\beta^{-}$ & & $\begin{array}{c}0.07 * \\
(0.037)\end{array}$ & $\begin{array}{l}0.071^{*} \\
(0.038)\end{array}$ & $\begin{array}{c}0.768 \\
(0.457)\end{array}$ & & $\begin{array}{l}0.074 * \\
(0.042)\end{array}$ & $\begin{array}{l}0.073 * \\
(0.043)\end{array}$ & $\begin{array}{c}0.699 \\
(0.454)\end{array}$ \\
\hline Upside $\beta^{+}$ & & $\begin{array}{c}0.002 \\
(0.035)\end{array}$ & $\begin{array}{c}0.002 \\
(0.035)\end{array}$ & $\begin{array}{c}0.772 \\
(0.555)\end{array}$ & & $\begin{array}{c}0.041 \\
(0.043)\end{array}$ & $\begin{array}{c}0.041 \\
(0.043)\end{array}$ & $\begin{array}{c}0.667 \\
(0.534)\end{array}$ \\
\hline Ln(Mkt Cap) & $\begin{array}{c}-0.001 \\
(0.007)\end{array}$ & $\begin{array}{c}0.001 \\
(0.007)\end{array}$ & $\begin{array}{c}0.001 \\
(0.007)\end{array}$ & $\begin{array}{l}20.835 \\
(2.096)\end{array}$ & $\begin{array}{c}-0.01 \\
(0.009)\end{array}$ & $\begin{array}{l}-0.006 \\
(0.009)\end{array}$ & $\begin{array}{l}-0.006 \\
(0.009)\end{array}$ & $\begin{array}{l}20.734 \\
(2.171)\end{array}$ \\
\hline Book-to-Market & $\begin{array}{l}0.175^{*} \\
(0.030)\end{array}$ & $\begin{array}{c}0.177 * * * \\
(0.030)\end{array}$ & $\begin{array}{c}0.178 * * * \\
(0.031)\end{array}$ & $\begin{array}{l}0.917 \\
(0.51)\end{array}$ & $\begin{array}{l}0.095 * * \\
(0.041)\end{array}$ & $\begin{array}{l}0.104 * * \\
(0.042)\end{array}$ & $\begin{array}{l}0.102 * * \\
(0.043)\end{array}$ & $\begin{array}{l}(0.816) \\
(0.427)\end{array}$ \\
\hline Momentum & $\begin{array}{c}-0.082 * * \\
(0.033)\end{array}$ & $\begin{array}{l}-0.08 * * \\
(0.033)\end{array}$ & $\begin{array}{c}-0.079 * * \\
(0.033)\end{array}$ & $\begin{array}{c}0.052 \\
(0.336)\end{array}$ & $\begin{array}{l}-0.08^{*} \\
(0.042)\end{array}$ & $\begin{array}{l}-0.069^{*} \\
(0.041)\end{array}$ & $\begin{array}{l}-0.07 * \\
(0.041)\end{array}$ & $\begin{array}{c}0.089 \\
(0.329)\end{array}$ \\
\hline Volatility & $\begin{array}{c}-11.614 * * * \\
(0.949)\end{array}$ & $\begin{array}{c}-11.352 * * * \\
(0.929)\end{array}$ & $\begin{array}{c}-11.352 * * * \\
(0.928)\end{array}$ & $\begin{array}{c}0.022 \\
(0.013)\end{array}$ & $\begin{array}{l}-13.25^{* * * *} \\
(1.722)\end{array}$ & $\begin{array}{c}-12.387 * * * \\
(1.750)\end{array}$ & $\begin{array}{l}-12.4 * * * \\
(1.751)\end{array}$ & $\begin{array}{c}0.019 \\
(0.009)\end{array}$ \\
\hline Coskewness & $\begin{array}{c}-0.084 * * \\
(0.042)\end{array}$ & $\begin{array}{c}-0.04 \\
(0.051)\end{array}$ & $\begin{array}{c}-0.04 \\
(0.053)\end{array}$ & $\begin{array}{l}-0.061 \\
(0.192)\end{array}$ & $\begin{array}{c}-0.123 * * \\
(0.052)\end{array}$ & $\begin{array}{l}-0.103 \\
(0.065)\end{array}$ & $\begin{array}{l}-0.105 \\
(0.068)\end{array}$ & $\begin{array}{l}-0.066 \\
(0.203)\end{array}$ \\
\hline Cokurtosis & $\begin{array}{c}-0.028 * * * \\
(0.008)\end{array}$ & $\begin{array}{c}-0.022 * * * \\
(0.008)\end{array}$ & $\begin{array}{c}-0.022 * * * \\
(0.008)\end{array}$ & $\begin{array}{c}1.971 \\
(1.408)\end{array}$ & $\begin{array}{c}-0.05 * * * \\
(0.016)\end{array}$ & $\begin{array}{c}-0.043 * * \\
(0.017)\end{array}$ & $\begin{array}{c}-0.043 * * \\
(0.017)\end{array}$ & $\begin{array}{l}1.526 \\
(1.119)\end{array}$ \\
\hline Liquidity Beta & & & $\begin{array}{l}-0.005 \\
(0.044)\end{array}$ & $\begin{array}{c}-0.017 \\
(0.246)\end{array}$ & & & $\begin{array}{c}0.012 \\
(0.050)\end{array}$ & $\begin{array}{l}-0.012 \\
(0.268)\end{array}$ \\
\hline $\begin{array}{l}\text { Mean Adjust R }{ }^{2} \\
\text { F-statistics }\end{array}$ & $\begin{array}{c}0.237 * * * \\
(13.27)\end{array}$ & $\begin{array}{l}0.234 * * * \\
(14.84)\end{array}$ & $\begin{array}{c}0.234 * * * \\
(17.2)\end{array}$ & & $\begin{array}{c}0.290 * * * \\
(14.02)\end{array}$ & $\begin{array}{c}0.297 * * * \\
(11.36)\end{array}$ & $\begin{array}{c}0.297 * * * \\
(10.09)\end{array}$ & \\
\hline
\end{tabular}

$* * *, * *, *$ indicate statistical significance at $0.01,0.05$ and 0.1 level, respectively. 
Table 6

\section{P\&C Insurers Fama-MacBeth Regressions (Insurers Controls), 1990-2012 vs 1990-2006}

This table shows the results of Fama-MacBeth (1973) regressions of overlapping 12-month excess returns on specific insurance firm characteristics and realized risk characteristics. The sample period is from January 1990 to December 2012 for the full sample period on the left and from January 1990 to December 2006 for the sub-sample period on the right. Observations are at a monthly frequency for all publicly-traded P\&C insurance companies. The $t$-statistics computed using Newey-West (1987) heteroskedastic-robust standard errors are reported in parentheses. Realized risk characteristics and insurer-specific controls are defined in Table 1. All independent variables are winsorized at the $1 \%$ level and at the $99 \%$ level within each quarter. The last column reports time-series averages of the cross-sectional mean and standard deviation (in parentheses) of each independent variable.

\begin{tabular}{|c|c|c|c|c|c|c|c|c|}
\hline & \multicolumn{4}{|c|}{ Full Sample Period: 1990-2012 } & \multicolumn{4}{|c|}{ Sub-Sample Period: 1990-2006 } \\
\hline $\begin{array}{l}\text { Model } \\
\text { Control Variable }\end{array}$ & I & II & III & $\begin{array}{c}\text { Mean } \\
\text { (Std.Dev.) }\end{array}$ & I & II & III & $\begin{array}{c}\text { Mean } \\
\text { (Std.Dev.) }\end{array}$ \\
\hline Intercept & $\begin{array}{c}0.446 * * * \\
(0.133)\end{array}$ & $\begin{array}{c}0.403 * * * \\
(0.135)\end{array}$ & $\begin{array}{c}0.411 * * * \\
(0.136)\end{array}$ & & $\begin{array}{c}0.587 * * * \\
(0.168)\end{array}$ & $\begin{array}{c}0.515^{* * *} \\
(0.173)\end{array}$ & $\begin{array}{c}0.538 * * * \\
(0.175)\end{array}$ & \\
\hline CAPM $\beta$ & $\begin{array}{c}0.127 * * * \\
(0.040)\end{array}$ & & & $\begin{array}{c}0.763 \\
(0.422)\end{array}$ & $\begin{array}{c}0.189 * * * \\
(0.046)\end{array}$ & & & $\begin{array}{c}0.675 \\
(0.393)\end{array}$ \\
\hline Downside $\beta^{-}$ & & $\begin{array}{l}0.09 * * \\
(0.039)\end{array}$ & $\begin{array}{c}0.089 * * \\
(0.04)\end{array}$ & $\begin{array}{c}0.768 \\
(0.457)\end{array}$ & & $\begin{array}{l}0.094 * * \\
(0.044)\end{array}$ & $\begin{array}{l}0.09 * * \\
(0.045)\end{array}$ & $\begin{array}{c}0.699 \\
(0.454)\end{array}$ \\
\hline Upside $\beta^{+}$ & & $\begin{array}{l}-0.005 \\
(0.037)\end{array}$ & $\begin{array}{l}-0.004 \\
(0.038)\end{array}$ & $\begin{array}{c}0.772 \\
(0.555)\end{array}$ & & $\begin{array}{c}0.039 \\
(0.045)\end{array}$ & $\begin{array}{c}0.041 \\
(0.046)\end{array}$ & $\begin{array}{c}0.667 \\
(0.534)\end{array}$ \\
\hline $\operatorname{Ln}(\mathrm{BV})$ & $\begin{array}{l}-0.013 * \\
(0.007)\end{array}$ & $\begin{array}{c}-0.01 \\
(0.007)\end{array}$ & $\begin{array}{c}-0.01 \\
(0.007)\end{array}$ & $\begin{array}{l}22.360 \\
(2.033)\end{array}$ & $\begin{array}{c}-0.018 * * \\
(0.009)\end{array}$ & $\begin{array}{l}-0.014 \\
(0.009)\end{array}$ & $\begin{array}{l}-0.014 \\
(0.009)\end{array}$ & $\begin{array}{l}22.277 \\
(2.018)\end{array}$ \\
\hline Leverage & $\begin{array}{c}0.132 \\
(0.109)\end{array}$ & $\begin{array}{c}0.117 \\
(0.110)\end{array}$ & $\begin{array}{c}0.116 \\
(0.110)\end{array}$ & $\begin{array}{c}0.763 \\
(0.122)\end{array}$ & $\begin{array}{c}0.157 \\
(0.149)\end{array}$ & $\begin{array}{c}0.124 \\
(0.152)\end{array}$ & $\begin{array}{c}0.118 \\
(0.151)\end{array}$ & $\begin{array}{c}0.778 \\
(0.116)\end{array}$ \\
\hline Momentum & $\begin{array}{c}-0.159 * * * \\
(0.037)\end{array}$ & $\begin{array}{c}-0.156 * * * \\
(0.037)\end{array}$ & $\begin{array}{c}-0.157 * * * \\
(0.037)\end{array}$ & $\begin{array}{c}0.052 \\
(0.336)\end{array}$ & $\begin{array}{c}-0.129 * * * \\
(0.045)\end{array}$ & $\begin{array}{c}-0.119 * * * \\
(0.044)\end{array}$ & $\begin{array}{c}-0.122 * * * \\
(0.044)\end{array}$ & $\begin{array}{c}0.089 \\
(0.329)\end{array}$ \\
\hline Volatility & $\begin{array}{c}-11.393 * * * \\
(1.109)\end{array}$ & $\begin{array}{c}-11.074 * * * \\
(1.105)\end{array}$ & $\begin{array}{c}-11.09 * * * \\
(1.109)\end{array}$ & $\begin{array}{c}0.022 \\
(0.013)\end{array}$ & $\begin{array}{c}-13.729 * * * \\
(1.831)\end{array}$ & $\begin{array}{c}-12.81 * * * \\
(1.879)\end{array}$ & $\begin{array}{c}-12.855 * * * \\
(1.879)\end{array}$ & $\begin{array}{c}0.019 \\
(0.009)\end{array}$ \\
\hline Coskewness & $\begin{array}{c}-0.116^{* * *} \\
(0.044)\end{array}$ & $\begin{array}{l}-0.055 \\
(0.053)\end{array}$ & $\begin{array}{l}-0.058 \\
(0.054)\end{array}$ & $\begin{array}{l}-0.061 \\
(0.192)\end{array}$ & $\begin{array}{l}-0.129 * * \\
(0.053)\end{array}$ & $\begin{array}{l}-0.097 \\
(0.064)\end{array}$ & $\begin{array}{l}-0.105 \\
(0.066)\end{array}$ & $\begin{array}{l}-0.066 \\
(0.203)\end{array}$ \\
\hline Cokurtosis & $\begin{array}{c}-0.027 * * * \\
(0.008)\end{array}$ & $\begin{array}{c}-0.019 * * \\
(0.009)\end{array}$ & $\begin{array}{c}-0.018 * * \\
(0.009)\end{array}$ & $\begin{array}{c}1.971 \\
(1.408)\end{array}$ & $\begin{array}{c}-0.06 * * * \\
(0.016)\end{array}$ & $\begin{array}{c}-0.053 * * * \\
(0.016)\end{array}$ & $\begin{array}{c}-0.051 * * * \\
(0.016)\end{array}$ & $\begin{array}{c}1.526 \\
(1.119)\end{array}$ \\
\hline Liquidity Beta & & & $\begin{array}{c}0.023 \\
(0.045)\end{array}$ & $\begin{array}{l}-0.017 \\
(0.246)\end{array}$ & & & $\begin{array}{c}0.044 \\
(0.049)\end{array}$ & $\begin{array}{l}-0.012 \\
(0.268)\end{array}$ \\
\hline $\begin{array}{l}\text { Mean Adjust } \mathrm{R}^{2} \\
\text { F-statistics }\end{array}$ & $\begin{array}{l}0.171 * * * \\
(8.69)\end{array}$ & $\begin{array}{c}0.167 * * * \\
(9.79)\end{array}$ & $\begin{array}{c}0.168^{* * *} \\
(11.49)\end{array}$ & & $\begin{array}{l}0.271^{* * *} \\
(9.27)\end{array}$ & $\begin{array}{c}0.246^{* * *} \\
(10.39)\end{array}$ & $\begin{array}{c}0.248 * * * \\
(13.42)\end{array}$ & \\
\hline
\end{tabular}

***,**,*indicate statistical significance at $0.01,0.05$ and 0.1 level, respectively. 


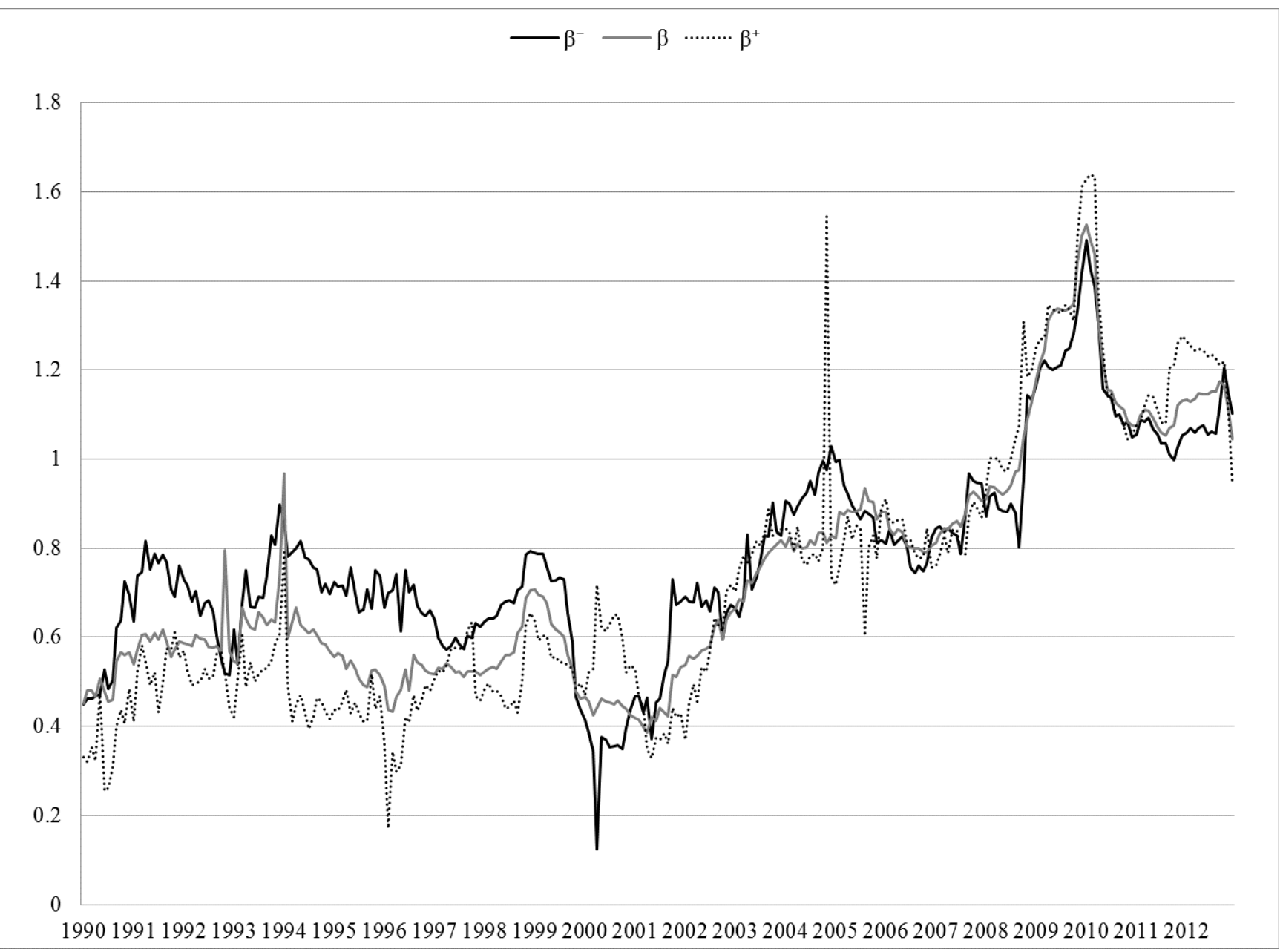

Figure 1

\section{Average realized $\beta^{-}, \beta$, and $\beta^{+}$for U.S. life insurers, 1990-2012}

Traditional CAPM $\beta$, upside beta $\beta^{+}$, and downside beta $\beta^{-}$are calculated for overlapping 12 -month periods of daily excess returns for all publicly-traded life insurers relative to daily market excess returns, with the CRSP value-weighted equity return index as the market proxy. Upside betas are calculated conditional on market excess return being larger than the market average excess return. Downside betas are calculated conditional on market excess returns being less than the market average excess return. 